\title{
САМОУПРАВЛІННЯ ПРОФЕСІЙНИМ РОЗВИТКОМ ВИКЛАДАЧІВ КАФЕДР МЕНЕДЖМЕНТУ ПОЛЬСЬКИХ ЗАКЛАДІВ ВИЩОЇ ОСВІТИ У СИСТЕМІ ВІДКРИТОЇ ОСВІТИ
}

\begin{abstract}
У статті розглянуто можливі форми самоуправління професійним розвитком викладачів кафедр менеджменту закладів вищої освіти Республіки Польща у системі відкритої освіти. Проаналізовано причини виникнення відкритої освіти та ї̈ значення в самоуправлінні професійним розвитком викладачів. Основна увага приділена такій формі розвитку професійного рівня викладача, як е-learning. Охарактеризовано види електронного навчання, описано його можливості та вплив на професійний розвиток викладачів кафедр менеджменту польських закладів вищої освіти у системі відкритої освіти.
\end{abstract}

Ключові слова: e-learning, професійний розвиток, самоосвіта, саморозвиток, самоуправління, система відкритої освіти.

Вступ. Останні десятиліття розвитку світового суспільства характеризують значні зміни, які пов'язані 3 новими технологіями і їх застосуванням у всіх сферах життя. Сучасний мешканець Свропи і світу не уявляє свого функціонування в суспільстві без цифрових технологій, які стали інтегральною частиною спілкування, обміну інформацією та досвідом, отримання нових знань.

Нові інформаційні технології, безумовно, впливають на способи і форми навчання у системі вищої освіти. Молоді люди, які багато подорожують, спілкуються за допомогою цифрових технологій із колегами з різних країн, мають можливість порівняти доступ до системи вищої освіти у різних країнах. Зросла кількість дорослого населення, яке прагне отримати післядипломну освіту чи закінчити курси, які сформують або розвинуть ті чи інші компетентності. Досить часто студенти хочуть поєднувати навчання 3 роботою, що вимагає більшої еластичності в побудові навчального процесу [1: 10].

У результаті Болонського процесу та плану модернізації системи вищої освіти Свросоюзу відбуваються великі зміни, що стосуються відкритої освіти, яка покликана задовольнити потребу сучасного студента в індивідуальному підході до темпів навчання, обрання дидактичних матеріалів (аудіовізуальних чи графічних).

Постановка проблеми. Аналіз свідчить, що відкрита освіта сьогодні є важливою проблемою, яка піднімається в польських наукових колах. Масове відкрите Інтернет-навчання на загальноєвропейській платформі МООС [1], головним чином, спричинило дискусії щодо впровадження відкритої освіти в університетську систему, тому що відкрилися нові можливості навчання у відкритому просторі громадянам різних країн. Із огляду на це, з одного боку, відкрита освіта у системі вищої освіти Республіки Польща відкриває великі можливості у складній демографічній ситуації, яка склалася в Польщі в останні десятиліття, а з іншого - ставить нові вимоги до системи освіти, технологій, методик, засобів навчання. Дискусія щодо можливостей і обмежень відкритої освіти формує в Польщі нове ставлення до того, хто навчається. Відкритість освіти змінює освітню практику, концентрується на співпраці, індивідуалізації та персоналізації навчання, дозволяє тому, хто навчається, будувати індивідуальну стежку розвитку.

Для цього необхідно змінювати свідомість учасників освітнього процесу, розвивати компетентності викладачів - і тих, хто навчає, і тих, хто навчається, та створювати позитивну атмосферу суспільного сприйняття відкритої освіти.

Мета даної наукової розвідки полягає в аналізі та характеристиці форм і шляхів самоуправління професійним розвитком викладачів кафедр менеджменту польських закладів вищої освіти 3 використанням системи відкритої освіти.

Відкрита освіта не може функціонувати без відкритих навчальних засобів. Вони загальнодоступні (підручники, курси, конспекти лекцій та ін.), безкоштовні, 3 правом подальшого використання та адаптації [2]. Термін "відкриті навчальні засоби" (з англ. Open Educational Resourses - скорочено OER) вперше був використаний у 2002 році під час Forum on the Impact of Open Courseware for Higher Education in Developing Countries при ЮНЕСКО. Створився міжнародний рух OER, який має на меті вирівняти освітні шанси усіх учасників відкритої освіти.

У Польщі в 2008 році була створена неформальна Коаліція відкритої освіти, яка в 2015 році нараховувала 32 організації та має за завдання розбудову системи відкритої освіти в Польщі. На сьогодні повною мірою відповідає європейським вимогам щодо відкритої освіти платформа Гірничометалургійної академії ім. Станіслава Сташіца у Кракові, яка 8 січня 2010 року відкрила сервіс Ореп 
AGH, на якому працівники, докторанти, студенти діляться розробленими, опрацьованими навчальними і науковими матеріалами [3].

У Варшавському університеті в 2008 році було створено Відкритий університет, у рамках якого близько 40 тисяч слухачів є учасниками відкритих курсів, лекцій, наукових дебатів. Навчальний рік складається із трьох триместрів. У кожному триместрі викладається близько 250 курсів, кожен із них $є$ авторським. Із Відкритим університетом співпрацює близько 500 викладачів. Після закінчення курсу слухач отримує диплом із кількістю прослуханих годин курсу, якщо слухач здає іспит, то отримує сертифікат, який підтверджує рівень знань [4].

Професійний розвиток викладачів кафедр менеджменту закладів вищої освіти Республіки Польща на сьогодні є досить актуальною проблемою, оскільки вимога до нього відображена в нормативно-правовій базі та документах закладів вищої освіти. 3 огляду на великий обсяг обов'язків, які виконує викладач, $\mathrm{i}$ враховуючи стрімкий розвиток інформаційно-комунікаційних технологій, e-learning стає досить популярною формою здобуття інформації викладачами та розвитку їхніх компетентностей.

Аналіз актуальних досліджень. Питання використання e-learning як ефективної форми самоосвіти вивчається широким колом науковців. Серед українських дослідників значення e-learning в професійному розвитку педагогів досліджують Ю. Биков, А. Гуржій, С. Касьян, Л. Ляхоцька, Т. Махиня, В. Олійник, 3. Рябова, серед польських науковців проблема e-learning є предметом досліджень науковців І. Гарнік, А. Запаса, Л. Кожьол, М. Кожьол, Й. Колоджєй, П. Комада, П. Копчял, К. Реглярські. Однак не існує комплексного дослідження, яке б аналізувало роль e-learning, як однієї з технологій відкритої освіти, у розвитку професійної компетентності викладачів кафедр менеджменту закладів вищої освіти Республіки Польща.

У польських закладах вищої освіти, як і в українських, професійний розвиток викладачів відбувається завдяки планованому управлінню й самоуправлінню. Ми розглянемо професійний розвиток викладачів кафедр менеджменту польських закладів освіти і шляхи самоуправління ним. Значну увагу акцентуємо на e-learning, який серед усіх форм підвищення рівня професіоналізму викладачів кафедр менеджменту посідає головну позицію.

Для того, щоб викладач сам спланував свій професійний розвиток, він має усвідомлювати кілька позицій: 1) яким $є$ рівень його професіоналізму; 2) яким він має бути у найближчій і дальшій перспективах; 3) що потрібно зробити для того, щоб досягнути очікуваного рівня професіоналізму.

Аналізуючи можливості самоуправління професійним розвитком викладачів кафедр менеджменту польських закладів освіти у системі відкритої освіти, зупинимося на формах, за умови використання яких можливий розвиток професіоналізму викладачів. У цій статті братимемо до уваги сучасні вимоги, запити й очікування як польського суспільства, керівництва закладу, студента, так і, власне, самого викладача.

Із огляду на неперервну освіту, яка відображена в Законі про вищу освіту Польщі, вона стосується оновлення і поглиблення загальних знань, умінь і професійних кваліфікацій як працівників, так i працедавців [5: 83].

Формами неперервної освіти, складовими відкритої освіти, є курси, навчання, семінари. Вони можуть організовуватися як за місцем роботи, так і поза ним. Науковці Г. Круль, А. Людвічинський виділяють і характеризують такі форми навчання [6: 468-473]:

Поза місцем роботи: лекція, дискусія.

На місці роботи: інструктаж, коучінг, менторінг.

Метою курсів і навчань $\epsilon$, передусім, розширення знань особи - працівника в певній галузі. Риси, які характеризують навчання - це систематичність і плановість. Навчання і курси дають змогу викладачеві здобути знання, які потрібні для реалізації завдань, що ставляться перед ним кафедрою і закладом. Також вони створюють можливості для заспокоєння потреб закладу вищої освіти у сфері формування іiі кадрової політики [7]. У нашому випадку, на основі SWOT-аналізу відбуваються планові курси i навчання, скеровані на формування компетентностей викладачів, які є необхідними зараз і в найближчій перспективі.

Аналізуючи проблематику курсів і навчань викладачів, охарактеризуємо процедуру їх організації. Вона містить кілька етапів [7: 7]:

Попередні очікування і пропозиції, ідентифікація та аналіз навчальних потреб.

Окреслення мети навчання, його проектування.

Проведення навчання.

Звіт про проведене навчання.

Моніторинг і оцінка здійсненого навчання.

Підсумок освітнього процесу.

Як підкреслюють автори колективної монографії "Розвиток особистий і професійний. Вибрані проблеми теорії та практики", до 90-х років XX ст. у польській літературі поняття "навчання" (szkolenie прим. авт.) і поняття "курс" (kurs - прим. авт.) були взаємозамінними. Однак нині науковці відзначають, що курс $є$ ширшим поняттям, ніж навчання [8: 61]. 
Варто зазначити, що однією із важливих форм професійного розвитку викладачів кафедр менеджменту є післядипломне навчання. Згідно із Законом про вищу освіту Республіки Польща, післядипломне навчання - це форма навчання, якою можуть скористатися ті особи, які мають перший ступінь кваліфікації [5]. Це навчання відрізняється від описаних вище тим, що має конкретну структуру, відповідає Національній рамці кваліфікацій, згідно з польським законодавством тривалість навчання становить не менше як два семестри і результат навчання - захист післядипломної праці та отримання диплома, який відповідає тому чи іншому ступеню кваліфікації. У навчальних програмах післядипломного навчання передбачено велику кількість годин на самостійне опрацювання, тобто на самоосвіту.

Під поняттям самоосвіти розуміється самостійне здобування знань. Польський науковець Д. Янковський термін "самоосвіта" формулює таким чином: "самоосвіта - це процес, тобто ряд логічно пов'язаних між собою, точно організованих дій особи, яка навчається, має на меті самостійне, без керівництва вчителя отримання потрібної інформації, інтелектуальних і мануальних властивостей, а також розвиток пізнавальних здібностей: спостереження, уваги, уяви, пам'яті та критичного мислення" [9: 120-121].

Професійний розвиток викладача, підвищення його кваліфікації прямо пропорційно пов'язані із ринком праці, який досить динамічно змінюється. Технологічний та інформаційний розвиток суспільства призвели до того, що в кожній галузі Інтернет відіграє значну роль. Освіта і наука не є виключеннями. Застосування інформаційно-комунікаційних технологій навчання призвели до створення нової системи, яка називається e-learning i надає можливість проводити навчання, курси, семінари, а також реалізовувати післядипломне навчання. Використання вищезгаданої системи допомагає викладачеві ефективно займатися самоосвітою і розвитком професійного рівня, використовуючи переваги відкритої освіти.

У загальновідомій дефініції зазначено, що е-learning - це навчання за посередництвом Інтернету. У польській мові це визначення має кілька синонімів: "е-навчання", "навчання на відстані", "дистанційне навчання". Величезним плюсом такого навчання $€$ те, що особа, яка навчається, може підвищувати свій професійний рівень у зручний для себе час і зручному місці [10: 48]. У наукових джерелах дефініція "еlearning" є ширшою. Вона стосується навчання, яке підтримується такими засобами, як: комп’ютерні програми, платформи, електронні сайти, сторінки, освітні портали і сервіси, навчальні та дидактичні матеріали на змінних електронних носіях [11].

Автори монографії "Розвиток особистий i професійний. Вибрані проблеми теорії та практики" [12: 111] зазначають, що e-learning відрізняється від очного навчання тим, що у того, хто навчається, має бути досить високою мотивація в навчанні, адже в процесі е-навчання оптимізуються контакти з тим, хто навчає. Той, хто навчається, повинен розвивати власну силу волі, мотивувати себе до опрацювання матеріалу, до виконання завдань.

Як свідчать дані анкетування, на цьому етапі викладачі кафедр менеджменту найчастіше обирають дистанційні курси і навчання, які, зазвичай, відбуваються за допомогою платформи e-learning. Причиною цього $є$ зменшення витрат (економія на проживанні, проїзді), поєднання роботи з навчанням (навчання у позаробочий час), управління своїм часом і можливість навчатися в зручному для себе місці. Викладачі зазначають, що курси і навчання за допомогою платформи e-learning дають змогу в зручний для них час працювати із матеріалами, постійно перевіряючи рівень засвоєної інформації, контролювати свої успіхи в навчанні, постійно бути в контакті 3 авторами навчальних матеріалів, модераторами, маючи можливість задавати їм запитання й отримувати на них відповіді.

У "Пораднику e-learning" автор зазначає, що найчастіше складовими навчальних матеріалів на платформі використовуються:

текст;

прості графічні та мультимедійні елементи, такі як фотографії, рисунки і анімації;

фільми і звукові файли, які містять навчальну інформацію;

тести і завдання;

різноманітні контрольні запитання і завдання, лексикони, допоміжні файли, гіперпосилання [10: 16].

На жаль, не у всіх польських закладах вищої освіти завжди використовуються повною мірою можливості e-learning. Причиною цього є невідповідність технічних можливостей вимогам забезпечення e-learning; прив'язаність керівництва до стандартних форм навчання, переважання стереотипу викладачів середнього і старшого віку, які вважають, що очне навчання під час курсів, навчань, післядипломної освіти сприяє підвищенню рівня фахових компетентностей; 85 \% опитаних викладачів, віком 60 років і більше, стверджують, що самоосвіта ефективна під час опрацювання книг і статей у друкованому варіанті в читальних залах чи вдома; $90 \%$ викладачів віком до 60 років надають перевагу Інтернетресурсам, електронним книгам і електронним статтям, хоча не виключають також опрацювання друкованих джерел. 
Промовистим є також той факт, що 28,6 \% опитаних викладачів отримали післядипломну освіту, при чому 71,4 \% - за допомогою e-learning.

Відзначимо, що з кожним роком кількість платформ у державних закладах вищої освіти Республіки Польща зростає. 3'являються центри дистанційного навчання, які формують курси, навчання, тренінги, семінари, виходячи із запитів клієнтів, їхніх вимог і побажань; недоліком, який відзначають викладачі, $\epsilon$ те, що такі форми електронного навчання, які пропонують центри дистанційного навчання, є платними. Незважаючи на це, польські вчені, серед них А. Кєлбус, М. Міровська, Ю. Гавлік, П. Комада, вважають, що в поєднанні традиційних та інноваційних форм навчання, серед яких все більш популярною стає еlearning, знаходиться майбутнє польської освіти і науки.

Проаналізувавши анкети викладачів кафедр менеджменту польських закладів вищої освіти, представимо найважливіші сторони e-learning, відображені в SWOT-аналізі (таблиця 1).

\section{E-learning у SWOT-аналізі}

Таблиия 1

\begin{tabular}{|c|c|}
\hline Сильні & Слабкі \\
\hline $\begin{array}{l}\text { Легкий і постійний доступ до навчальних } \\
\text { матеріалів ( } 24 \text { год. на добу); } \\
\text { менші фінансові витрати тих, хто навчається; } \\
\text { мобільність; } \\
\text { можливості навчання для осіб із особливими } \\
\text { потребами; } \\
\text { заощадження часу; } \\
\text { обрання зручного місця для навчання }\end{array}$ & $\begin{array}{l}\text { Обмежена мотивація у тих, хто навчається; } \\
\text { можливі технічні проблеми; } \\
\text { обмежена участь тих, хто навчається, у } \\
\text { практичних заняттях; } \\
\text { велика кількість часу і праці для підготовки } \\
\text { матеріалів тими, хто навчає і тими, хто } \\
\text { навчається }\end{array}$ \\
\hline Шанси & Загрози \\
\hline $\begin{array}{l}\text { Контакт із великою кількістю користувачів; } \\
\text { адресний супровід у навчанні; } \\
\text { підвищення іміджу установи, яка пропонує } \\
\text { платформи для електронного навчання; } \\
\text { швидкий контакт із тими, хто навчається; } \\
\text { моніторинг навчання; } \\
\text { збільшення кількості тих викладачів, які } \\
\text { навчаються в Польщі }\end{array}$ & $\begin{array}{l}\text { Обмежені можливості перевірки теоретичних } \\
\text { знань тих, хто навчається; } \\
\text { швидкий розвиток інформаційно-комунікаційних } \\
\text { технологій, що призводить до потреб купівлі } \\
\text { дорогих платформ; } \\
\text { неукомплектованість груп тих, хто навчається; } \\
\text { довіра не всіх працедавців до сертифікатів і } \\
\text { дипломів, отриманих викладачами у результаті е- } \\
\text { learning }\end{array}$ \\
\hline
\end{tabular}

\section{Джерело: Опрачювання власне}

Описані вище форми самоуправління професійним розвитком викладачів кафедр менеджменту польських закладів освіти: навчання, курси, семінари, післядипломна освіта, самоосвіта - поряд із очною формою, відбуваються у формі e-learning, яка з кожним роком стає більш популярною на польському освітньому ринку. Це пов'язано з тим, що e-learning дає можливість самостійно опрацьовувати матеріал, отримувати віртуальні консультації і працювати у зручному для викладача режимі.

Викладачі кафедр менеджменту таким чином висловили свою думку щодо шляхів і форм, які вони використовують із метою розвитку професійної компетентності. Потрібно зазначити, що можна було обирати кілька форм або зазначити інше:

самоосвіта $-71,4 \%$;

семінари - 71,4\%;

навчання $-37,5 \%$;

курси - 35,7\%;

стажування - 35,7\%

тренінги $-7,1 \%$.

Із них за допомогою інформаційно-комунікаційних технологій: курси $-28,6$ \%; навчання $-28,6$ \%; самоосвіта $-100 \%$.

Виходячи з цього, можемо зробити висновок, що отримуючи самостійно нові знання, вдосконалюючи існуючі компетентності або набуваючи нові, викладачі працюють у системі відкритої освіти, при цьому відзначають иї ефективність.

Поєднання традиційних форм навчання та e-learning носить назву blended learningu або b-learningu [13: 64-65]. У практичному використанні e-learning може повністю дублювати традиційну форму навчання, враховуючи особливості електронного навчання, або доповнювати традиційну форму навчання із тим співвідношенням, який визначить для себе викладач, який навчається.

Розвиток у польських закладах вищої освіти e-learning призвів до появи двох його напрямів: корпоративного й академічного [12]. Корпоративний e-learning направлений, передусім, на досягнення мети, яка пов'язана зі збільшенням конкурентоздатності фірми (у нашому випадку польського закладу вищої освіти) за посередництвом розвитку кадрового потенціалу (у цьому випадку - викладачів кафедр 
менеджменту). Як зазначає Л. Кожьол, "характерною рисою корпоративного e-learning є те, що він може відбуватися у відірваності від закладу освіти" [14: 64]. Що ж до академічного e-learning, то автор зазначає, що він "характеризується значно ширшими цілями, ніж удосконалення навчального процесу i його економічних процесів" [14: 64]. Це пов'язано з тим, що академічний e-learning має виконувати практично всі функції закладу освіти і перенести процес навчання в мережу. Л. Кожьол стверджує, що ці два напрямки e-learning розвиваються незалежно один від одного і відрізняються не лише цілями, а й методами, засобами, техніками і знаряддями, які слугують для їх реалізації [14: 64-65].

Як зазначалося вище, більшість викладачів кафедр менеджменту польських закладів вищої освіти у своїй професійній діяльності використовує Інтернет як джерело отримання нової інформації та можливість підвищити свій професійний рівень. У рамках самоосвіти викладачі $є$ відвідувачами і учасниками освітніх i наукових порталів, сайтів, мають власні електронні сайти, користуються послугами електронних бібліотек і книгарень, висловлюють свої думки на інтернет-форумах, черпають інформацію про конференції, семінари, курси, тренінги, післядипломне навчання і $є$ їх активними учасниками. На запитання, яким джерелам надають перевагу у викладацькій діяльності, 71,4\% викладачів відповіли - електронним джерелам і $28,6 \%$ - паперовим.

Варто відзначити, що 57,1 \% опитаних викладачів зазначили, що використовують e-learning у науково-дидактичній, науково-дослідницькій i організаційній діяльностях $\mathrm{i} \quad 42,9 \%$ викладачів використовують e-learning як учні, отримуючи нову інформацію, нові знання та вдосконалюючи професійні компетентності. Такі ж показники отримані при відповіді на запитання, чи використовуються інформаційно-комунікаційні технології викладачами під час занять: $57,1 \%$ викладачів відповіли, що використовують у разі потреби, 42,9 \% викладачів зазначили відповідь "так", жоден викладач не обрав відповіді "ні".

Варто зазначити, що в процесі самоуправління професійним розвитком викладачів кафедр менеджменту все частіше використовуються такі форми, як професійні блоги, сайти, портфоліо. Найчастіше вони не розміщені на сайті закладу вищої освіти, в якому працює викладач, а знаходяться у вільному доступі в мережі Інтернет.

На таких сайтах, блогах, у портфоліо викладача можна знайти коротку біографічну ноту автора, основні наукові зацікавлення, основні праці викладача, участь у проектах, грантах, міжнародних програмах, досягнення. Така форма самопрезентації свідчить про високий рівень професійної компетентності, мотивації до саморозвитку, готовність самореалізовуватися і допомагати в цьому іншим. Аналіз блогів, сайтів електронних портфоліо викладачів польських закладів вищої освіти дають змогу зробити висновок, що найчастіше це викладачі, які мають науковий ступінь доктора хабілітованого i наукове звання професора, з активними науковою і життєвою позиціями.

Прикладом зазначеної форми професійного розвитку є блог професора Яна Фазлягіча [15], відомого в Польщі та за ії межами науковця у сфері менеджменту в освіті та управління знаннями. Представлена форма $\epsilon$ прикладом самоуправління викладача професійною компетентністю у відкритому середовищі. Автор має можливість додавати власні матеріали, коригувати, а кожен користувач Інтернету, зацікавлений дослідженнями чи науковими працями професора Я. Фазлягіча має можливість легко та швидко сконтактувати $з$ автором, його науковим доробком і мобільно отримати відповіді на поставлені запитання.

Аналіз використання викладачами кафедр менеджменту закладів вищої освіти Республіки Польща платформ e-learning свідчить, що найчастіше вони користуються внутрішньо вузівською системою USOS - 85,7\% респондентів; 42,9\% викладачів користуються системою Moodle; 3 іншими платформами $57,1 \%$. Можна було обирати кілька варіантів відповідей.

Система USOS (Uniwersytecki System Obsługi Studiów - укр. Університетські Системи Обслуговування Навчання), була встановлена у Варшавському університеті на факультеті математики, інформатики і механіки в 2000 році як перша версія. Для цього було спеціально створено Консорціум MUCI (Międzynarodowe Centrum Informatyzacji - укр. Міжнародний Центр Інформатизації), завданням якого було розробити і розвивати власну систему керування навчально-організаційними процесами у закладах вищої освіти Республіки Польща. Така система діє у державних університетах Республіки Польща. У таблиці 2 подано державні навчальні заклади, які використовують систему USOS повною мірою.

Таблиия 2

Заклади вищої освіти Республіки Польща, що використовують систему USOS у розширеній версії

\begin{tabular}{|c|c|c|}
\hline $\begin{array}{l}\text { Noo } \\
3 / n\end{array}$ & Назва закладу вищої освіти РП & $\begin{array}{l}\text { Назва закладу вищой освіти РП } \\
\text { украӥнською мовою }\end{array}$ \\
\hline 1 & $\begin{array}{l}\text { Akademia Górniczo-Hutnicza im. Stanisława } \\
\text { Stasica w Krakowie }\end{array}$ & $\begin{array}{l}\text { Гірничо-металургійна академія ім. Станіслава } \\
\text { Сташіца а Кракові }\end{array}$ \\
\hline 2 & Politechnika Warszawska & Варшавська політехніка \\
\hline
\end{tabular}




\begin{tabular}{|l|l|l|}
\hline 3 & Uniwersytet im. Adama Mickiewicza w Poznaniu & $\begin{array}{l}\text { Познаньський } \\
\text { Міцкевича }\end{array}$ \\
\hline 4 & Uniwersytet w Białymstoku & Бялостоцький університет \\
\hline 5 & Uniwersytet Jagielloński & Ягеллонський університет \\
\hline 6 & Uniwersytet Kardynała Stefana Wyszyńskiego & Університет кардинала Стефана Вишинського \\
\hline 7 & Uniwersytet Kazimierza Wielkiego & Університет Казимира Великого \\
\hline 8 & Uniwersytet Łódzki & Лодзький університет \\
\hline 9 & Uniwersytet Marii Curie-Skłodowskiej & Університет Марії Кюрі-Склодовської \\
\hline 10 & Uniwersytet Mikołaja Kopernika & Університет Миколи Коперника \\
\hline 11 & Uniwersytet Opolski & Опольський університет \\
\hline 12 & Uniwersytet Rzeszowski & Ряшівський університет \\
\hline 13 & Uniwersytet Śląski & Сілезький університет \\
\hline 14 & Uniwersytet Warmińsko-Mazurski & Варміно-Мазурський університет \\
\hline 15 & Uniwersytet Warszawski & Варшавський університет \\
\hline 16 & Uniwersytet Wrocławski & Вроцлавський університет \\
\hline 17 & Uniwersytet Zielonogórski & Зеленогурський університет \\
\hline
\end{tabular}

Джерело: опрачювання власне.

Он-лайн послуги в системі USOS відбуваються за допомогою трирівневої архітектури і пов'язані 3 такими безкоштовними інформаційно-комунікаційними технологіями як PHP, Smarty I Python.

Викладачі кафедр менеджменту досить активно працюють у системі USOS. Там містяться їх навантаження, навчальні програми, розклади занять і консультацій, відбувається індивідуальний супровід студентів (завдання, розв'язки, тести, контрольні роботи, оцінки, наукове керівництво написанням курсових $\mathrm{i}$ дипломних робіт). У багатьох університетах використовується також загальнодоступний інтерфейс для інтеграції системи USOS 3 іншими електронними системами, які функціонують у закладі вищої освіти - USOS API. Також USOS може співпрацювати з локальними системами конкретного університету. У Варшавському університеті USOS під’єднаний до серверу електронної пошти, до центрального серверу авторизації, до електронного навчання на платформі Moodle та до бібліотечної системи VTLS.

На рисунку 2 представлено головну сторінку системи USOS Варшавського університету.

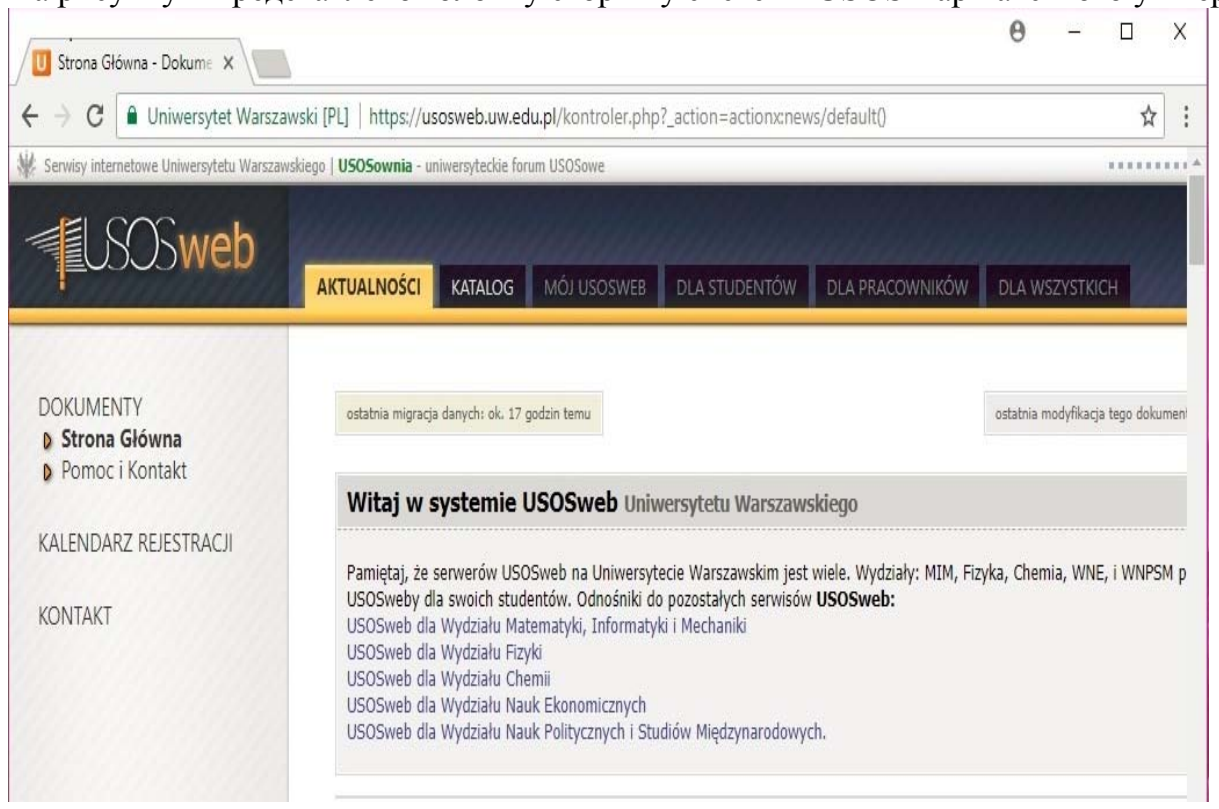

Рис. 2 Головна сторінка системи USOS Варшавського університету

Для порівняння в 2005 році систему USOS використовували $14 \%$ державних польських закладів вищої освіти, а в 2016 році таких закладів вищої освіти було вже $32 \%$, 3 кожним роком кількість університетів збільшується, що свідчить про перехід польської системи вищої освіти до діяльності в рамах відкритої освіти [4].

Коротко представимо функції основних модулів USOS, які використовують у своїй діяльності викладачі кафедр менеджменту. Це USOSweb, Ankieter i APD, UL.

USOSweb - це Інтернет аплікація, яка дає змогу спілкуватися викладачеві 3 адміністрацією університету і студентами. Доступ містить авторизацію для кожного користувача. У цій системі викладач 
може розміщувати протоколи заліків, іспитів, повідомляти про оцінки за контрольні роботи, тестові завдання.

Ankieter (укр. особа, яка здійснює опитування) - це портал університету, який містить анкети і опитувальники для студентів і викладачів.

У Варшавському університеті є створений Кабінет оцінювання якості освіти (польською РЕЈК Pracownia Ewaluacji Jakości Kształcenia), який має за мету здійснювати моніторинг якості освіти в університеті.

На вищезгаданому порталі містяться:

Анкети до занять і загальні анкети.

Запитання до предметів і загальні запитання.

Подається визначена шкала оцінювання за правильні відповіді.

Розміщуються коментарі.

Подається визначений діапазон видимості результатів анкет.

6. Можливість використання студентських анкет для оцінювання діяльності викладачів. Для цього використовується аплікація EVA (Ewaluacja Pracowników - укр. Оцінювання працівників).

APD (Archiwum Prac Dyplomowych - укр. Архів дипломних робіт) - сервіс, на якому зберігаються дипломні праці бакалаврів і магістрів даного закладу вищої освіти у форматі рdf. Викладачі реєструються на даному сервісі, якщо вони є науковими керівниками або рецензентами випускних робіт. Керівник і рецензент мають доступ лише до роботи, яку мають рецензувати або здійснювати наукове керівництво.

UL (Uniwersyteckie Lektoraty - укр. Університетські заняття) - це реєстрація студентів за допомогою жетонів на заняття. Даний модуль дає змогу обмежувати кількість записаних студентів до тієї чи іншої групи (до уваги беруться викладач, день тижня і година). Для викладача - це змога бачити хто й скільки студентів зареєстровані до нього на той чи інший предмет.

Як зазначає В. Мосоров у науковій розвідці, "Система USOS - інформаційно-освітнє середовище вищих навчальних закладів Польщі" абсолютна більшість державних університетів використовують ию систему для організації навчальних процесів, проте така монополія має певні плюси $і$ мінуси. До плюсів належать використання поширеної версї, розвиток якої підтримує широке коло ВНЗ (закладів вищої освіти - прим. авт). Проте існує недолік, а саме, коли ВНЗ не має впливу на розвиток такого програмного продукту $і$ иілковито залежить від власника коду. Такою альтернативою для USOS y Польщзі є спроба ВНЗ збудувати власну інформаційну систему (наприклад, система ЕКS Лодзької політехніки). Час покаже, в якому напрямку піде інформатизація польських ВНЗ: чи в бік застосування універсальних систем, чи в бік поширення індивідуальних, які б відповідали потребам конкретного BH3 [4: 7].

У професійному розвитку викладачів кафедр менеджменту польських закладів освіти, поряд iз великими досягненнями, існує ряд проблем і перешкод у ефективному використанні широких можливостей відкритої освіти, а саме:

Переобтяження викладачів бюрократичними вимогами, організаційно адміністративними завданнями, що зменшує час на професійний розвиток, у тому числі й у системі відкритої освіти;

Прив’язаність викладачів до традиційних методів і методик навчання;

Низький рівень взаємопідтримки і обміну досвідом та інформацією;

Низький рівень цифрових компетенцій;

Відсутність системи стимулювання викладачів за створення відкритих освітніх засобів навчання.

У зв'язку з вищезазначеними проблемами, пропонуються такі рекомендації групі експертів, які відповідають у Республіці Польща за впровадження відкритої освіти:

Підготовка програм навчання і професійного вдосконалення викладачів у галузі створення відкритих освітніх засобів і користування ними;

Підтримка викладачів-експертів у галузі менеджменту для створення відкритих освітніх засобів за різними спеціальностями;

Впровадження системи винагород викладачів за створення відкритих освітніх засобів;

Виділення відповідного часу, призначеного на роботу над освітніми матеріалами для застосування у закладах вищої освіти та публікації відкритих освітніх засобів;

Розробка і запровадження легкодоступних та простих у застосуванні програми оцінки якості відкритих освітніх засобів.

Висновки i перспективи подальших досліджень. Враховуючи вищезазначене, можемо констатувати, що в процесі розвитку професійної компетентності викладачів кафедр менеджменту польських закладів вищої освіти велику роль відіграє самоуправління. У процесі самоуправління чільне місце займає неперервне навчання: курси, навчання, семінари, післядипломна освіта, самоосвіта, створення блогів, сайтів, портфоліо. Вищеперераховані форми здобуття нових знань усе частіше 
пропонуються викладачам закладів вищої освіти Республіки Польща у формі e-learning, яке є складовою відкритої освіти.

Аналіз анкетування викладачів та офіційних сайтів державних польських закладів вищої освіти дає підставу зробити висновок, що на сучасному етапі велику перевагу у процесі підвищення свого професійного рівня викладачі надають цифровим технологіям i e-learning. Це пов'язано з тим, що дана форма навчання економить час, кошти, пропонує різноманітні форми і способи розвитку компетентностей, дає змогу навчатися без відриву від робочого місця. Як викладачі, так і студенти державних закладів освіти Республіки Польща зазначають, що саме у такій формі, як e-learning, вбачають майбутне польської відкритої освіти.

\section{СПИСОК ВИКОРИСТАНИХ ДЖЕРЕЛ ТА ЛІТЕРАТУРИ}

1. Sprawozdanie dla komisji Europejskiej Nowe sposoby uczenia się i nauczania w szkolnictwie wyższym [Електронний pecypc]. - $\quad$ Режим доступу: http://www.erasmusplus.org.pl/wpcontent/uploads/2015/11/Modernizacja-2015.pdf (дата звернення: 11.05.2018).

2. Otwarta edukacja [Електронний pecypc]. - Режим доступу : http://koed.org.pl/pl/otwarta-edukacja (дата звернення: 11.05.2018).

3. Otwarte zasoby edukacyjne [Електронний ресурс]. - Режим доступу https://pl.wikipedia.org/wiki/Otwarte_zasoby_edukacyjne (дата звернення: 11.05.2018).

4. Мосоров В. Система USOS - інформаційно-освітнє середовище вищих навчальних закладів Польщі [Електронний ресурс] / В. Мосоров. - Режим доступу : http://www.irbis-nbuv.gov.ua/cgi-bin/irbis cc. 3-7 (дата звернення: 11.05.2018).

5. Ustawa z dnia 27 lipca 2005 roku. Prawo o szkolnictwie wyższym (Dz.U.Nr 164. poz.1365 z późniejszymi poprawkami) [Електронний ресурс]. - Режим доступу : https: //www.nauka.gov.pl (дата звернення: 11.05.2018).

6. Król H. Zarządzanie zasobami ludzkimi. Tworzenie kapitału ludzkiego organizacji / H. Król, A. Ludwiczyński // PWN. - Warszawa, 2007. - S. 468-473.

7. Garski K. Jak efektywnie szkolić pracowników / K. Garski, J. Gontarz // PARP. - Warszawa, 2009.

8. Listwan T. Kształcenie kadry menedżerskiej firmy / T. Listwan // KADRY. - Wrocław, 1998. - $176 \mathrm{~s}$.

9. Jankowski D. Twórczy rozwój jednostki w całożyciowych procesach edukacji i samoedukacji / D. Jankowski // Dialog o Kulturze i Edukacji. - 2012. - Nr 1. - S. 120-121.

10. Zapasa A. Poradnik e-learningu / A. Zapasa // Świdnik. - 2011. -61 s.

11. Europejski System Edukacji Elearningowej [Електронний ресурс]. - Режим доступу: http://www.esee.eu/index.php?id=171 (дата звернення: 11.05.2018).

12. Pestka D. Rozwój osobisty / D. Pestka, J. Kołodziej, K. Pujer // Wybrane problemy teorii i praktyki. EXANTE. Wrocław, 2017. - $111 \mathrm{~s}$

13. Kopciał P. Analiza metod e-learningowych stosowanych w kształceniu osób dorosłych / P. Kopciał // Zeszyty Naukowe Warszawskiej Wyższej Szkoły Informatyki. - 2013. - Nr 9(7). - $80 \mathrm{~s}$.

14. Kozioł L. Determinanty rozwoju e-learningu korporacyjnego / L. Kozioł // Zeszyty Naukowe Uniwersytetu Humanistyczno-Przyrodniczego w Siedlcach. - 2013. - Nr 98. - S. 64-65.

15. Fazlagić Jan, Ph.D. My specializations [Електронний ресурс] / Jan Fazlagić. - Режим доступу : http://fazlagic.pl (дата звернення: 11.05.2018).

\section{REFERENCES (TRASLATED \& TRANSLITERATED)}

1. Sprawozdanie dla komisji Europejskiej Nowe sposoby uczenia się i nauczania w szkolnictwie wyższym [Elektronnyi resurs]. $\quad-\quad$ Rezhym $\quad$ dostupu : http://www.erasmusplus.org.pl/wpcontent/uploads/2015/11/Modernizacja-2015.pdf (data zvernennia: 11.05.2018).

2. Otwarta edukacja [Elektronnyi resurs]. - Rezhym dostupu : http://koed.org.pl/pl/otwarta-edukacja (data zvernennia : 11.05.2018).

3. Otwarte zasoby edukacyjne [Elektronnyi resurs]. - Rezhym https://pl.wikipedia.org/wiki/Otwarte_zasoby_edukacyjne (data zvernennia: 11.05.2018).

4. Mosorov V. Systema USOS - informatsiino-osvitnie seredovyshche vyshchykh navchal'nykh zakladiv Polshchi [USOS System as Information Educational Environment in Polish Higher Education Institutions] [Elektronnyi resurs] / V. Mosorov. - Rezhym dostupu: http://www.irbis-nbuv.gov.ua/cgi-bin/irbiscc. 3-7 (data zvernennia : 11.05.2018).

5. Ustawa z dnia 27 lipca 2005 roku. Prawo o szkolnictwie wyższym (Dz.U.Nr 164. poz.1365 z późniejszymi poprawkami) [Elektronnyi resurs]. - Rezhym dostupu : https: //www.nauka.gov.pl (data zvernennia: 11.05.2018).

6. Król H. Zarządzanie zasobami ludzkimi. Tworzenie kapitału ludzkiego organizacji / H. Król, A. Ludwiczyński // PWN. - Warszawa, 2007. - S. 468-473.

7. Garski K. Jak efektywnie szkolić pracowników / K. Garski, J. Gontarz // PARP. - Warszawa, 2009.

8. Listwan T. Kształcenie kadry menedżerskiej firmy / T. Listwan // KADRY. - Wrocław, 1998. - $176 \mathrm{~s}$.

9. Jankowski D. Twórczy rozwój jednostki w całożyciowych procesach edukacji i samoedukacji / D. Jankowski // Dialog o Kulturze i Edukacji. - 2012. - Nr 1. - S. 120-121.

10. Zapasa A. Poradnik e-learningu / A. Zapasa // Świdnik. - 2011. -61 s.

11. Europejski System Edukacji Elearningowej [Elektronnyi resurs]. - Rezhym dostupu : http://www.esee.eu/index.php?id=171 (data zvernennia : 11.05.2018). 
12. Pestka D. Rozwój osobisty / D. Pestka, J. Kołodziej, K. Pujer // Wybrane problemy teorii i praktyki. EXANTE. Wrocław, 2017. - $111 \mathrm{~s}$.

13. Kopciał P. Analiza metod e-learningowych stosowanych w kształceniu osób dorosłych / P. Kopciał // Zeszyty Naukowe Warszawskiej Wyższej Szkoły Informatyki. - 2013. - Nr 9(7). - $80 \mathrm{~s}$.

14. Kozioł L. Determinanty rozwoju e-learningu korporacyjnego / L. Kozioł // Zeszyty Naukowe Uniwersytetu Humanistyczno-Przyrodniczego w Siedlcach. - 2013. - Nr 98. - S. 64-65.

15. Fazlagić Jan, Ph.D. My specializations [Elektronnyi resurs] / Jan Fazlagić. - Rezhym dostupu : http://fazlagic.pl (data zvernennia: 11.05.2018).

Андрощук И. Н. Самоуправление профессиональным развитием преподавателей кафедр менеджмента польских заведений высшего образования в системе открытого образования.

В статье рассмотрены возможные формы самоуправления профессиональным развитием преподавателей кафедр менеджмента заведений высшего образования Республики Польша в системе открытого образования. Основное внимание уделено такой форме профессионального развития, какеlearning. Проанализировано причины возникновения открытого образования и его значение $в$ самоуправлении профессиональным развитием преподавателя. Охарактеризованы виды электронного обучения, описаны его возможности и влияние на профессиональное развитие преподавателей кафедр менеджмента польских заведений высшего образования в системе открытого образования.

Ключевые слова: e-learning, профессиональное развитие, самообразование, саморазвитие, самоуправление, система открытого образования.

\section{Androshchuk I. M. Self-Administration Form of Professional Teachers' Development within Departments of Management of Polish Higher Educational Institutions in the Framework of Open Education System.}

Significant changes concerning new technologies and its use in all spheres of life characterize recent decades of the world society development. Open education cannot operate without open educational instruments. It is generally available (textbooks, courses, lecture notes, etc.), free of charge and marked by the further usage and adaptation rights. Many polish state universities widely use e-learning as one of the technologies of regulated access to educational content.

Nowadays the professional teachers' development is a topical problem within management departments of higher educational institutions in the Republic of Poland since the requirements to it are reflected in the legal framework and documents of higher educational institutions. It should be noted that 57,1\% of the interviewed teachers indicated they use e-learning in scientific and didactic, research and organizational activities and 42,9\% of teachers use e-learning as students receiving new information, new knowledge and improving professional competence. The same key figures were obtained asking questions about the use of information and communication technologies by teachers during classes: $57,1 \%$ of teachers answered that they used it if necessary, 42,9\% of teachers reported the answer "yes", no one chose the answer "no".

The analysis of the e-learning platform usage by teachers of management departments shows in higher educational institutions of the Republic of Poland that they the most frequently use the USOS internal system$85,7 \%$ of respondents; $42,9 \%$ of teachers use the Moodle system; other platforms $-57,1 \%$. Several answers could be chosen.

Therefore self-administration plays an important role in the process of professional development of the teachers' competence within management departments of polish higher educational institutions. Lifelong learning takes an important place in self-administration: courses, training, seminars, postgraduate education, self-education, blogging, websites, and portfolio. The analysis of questionnaires of teachers and official sites of state polish higher educational institutions leads to the conclusion that at the present stage the teachers give a preference to digital technologies and e-learning in the process of raising their professional level. This regards to the fact that this form of education saves time, money, suggests various forms and ways of competences development, allows studying on the job. Both teachers and students of state educational institutions of the Republic of Poland notice that future of polish open education is seen in the form like e-learning.

Key words: e-learning, professional development, self-education, self-administration, self-management, system of open education. 